\title{
Petrology and Genesis of the Italian Zeolite Tuffs Used in the Construction Industry ${ }^{\dagger}$
}

\author{
Michael G. Stamatakis *, Charalampos Vasilatos *(i) and Ioanna Stefania Stamataki
}

check for updates

Citation: Stamatakis, M.G.; Vasilatos, C.; Stamataki, I.S. Petrology and Genesis of the Italian Zeolite Tuffs Used in the Construction Industry. Mater. Proc. 2021, 5, 7. https:// doi.org/10.3390/materproc2021005007

Academic Editor: Evangelos Tzamos

Published: 28 October 2021

Publisher's Note: MDPI stays neutral with regard to jurisdictional claims in published maps and institutional affiliations.

Copyright: (c) 2021 by the authors. Licensee MDPI, Basel, Switzerland. This article is an open access article distributed under the terms and conditions of the Creative Commons Attribution (CC BY) license (https:/ / creativecommons.org/licenses/by/ $4.0 /)$.

\author{
Department of Economic Geology and Geochemistry, Faculty of Geology and Geoenvironment, National and \\ Kapodistrian University of Athens, 15784 Athens, Greece; s.stamataki@yahoo.com \\ * Correspondence: stamatakis@geol.uoa.gr (M.G.S.); vasilatos@geol.uoa.gr (C.V.) \\ + Presented at International Conference on Raw Materials and Circular Economy, Athens, Greece, \\ 5-9 September 2021.
}

\begin{abstract}
The Italian zeolitic tuffs have been intensely exploited by family companies and are used, mainly, as building, insulation and decorative stone, whereas the fine powder resulted during the cutting of the blocks is used for feedstock and soil amendment. XRD, XRF and SEM/EDS techniques have been applied to study the zeolitic samples collected from quarries of Naples, Bolsena and Sorano areas. Two different types of chabazite, have been identified; a Ca-rich and a $\mathrm{Ca}, \mathrm{Mg}, \mathrm{K}, \mathrm{Na}-$ rich, both accompanying K- and Na-rich phillipsite probably due to the chemistry of the original volcanic glass, but also to the presence of alkali and alkaline earths-rich pore fluids. All tuffs studied exhibit shoshonitic affinity and trachytic composition. The occurrence of glassy tuffs above those zeolitized tuffs studied, is a characteristic model for an early zeolite diagenesis of the volcanic glass in open hydrological systems.
\end{abstract}

Keywords: industrial minerals and rocks; building materials; igneous petrology; trace element geochemistry

\section{Introduction}

Large zeolite tuff deposits of sedimentary origin occur in several places across Europe, having Tertiary through Quaternary age [1]. Diagenetic transformation of an original volcanic glass in saline-alkaline lake, or shallow marine environment under normal or elevated heat flow rates caused the formation of a series of zeolite minerals, accompanied by authigenic K-feldspar, silica polymorphs and sometimes evaporites [2-5].

Zeolite tuffs of a range of qualities are used in construction as building stones and/or pozzolanic additives in cement, animal feeding, agriculture and certain environmental applications [6-8].

In Italy, zeolite deposits of commercial grade occur near Naples, north of Rome and close to Lake Bolsena, central Italy. Some of them have been used since the antiquity in constrictions, whereas, most of them are exploited commercially in agriculture and animal feeding in granulated material, whereas in situ cut blocks are used as building stones in Italy and abroad.

The aim of this study is to compare the Italian zeolite tuffs used in the construction industry in terms of mineralogy, petrology and geochemistry and to define the model for the formation of those deposits.

\section{Materials and Methods}

Zeolitized tuffs that are being used as construction materials had been sampled during geological fieldwork in south-central Italy i.e., near Naples, Rome and Viterbo-OeviettoPitigliano-Sorano. Those areas are considered to belong to three different volcanic districts, those of Naples, Vico and Bolsena. 


\subsection{Geology of the Zeolitic Deposits}

\subsubsection{Naples Area}

Northwest of Naples town there exist several abandoned and active quarries of the so called Tufo Giallo Napoletano [Neapolitanean Yellow Tuff-NYT]. From this area two representative samples, labelled as NA1 and NA6 were collected and analysed. Both rock samples belong to the formation of the Campanian ignimbrite that is the pyroclastic product of the Campi Flegrei volcanic area. The ignimbrite is of trachytic composition, mainly constituted by scoriae and pumice fragments set in a cineritic matrix [9-14]. Sample NA1 was collected from an active quarry, just on the northwest outskirts of Naples $\left[40^{\circ} 53^{\prime} 08.58^{\prime \prime} \mathrm{N}, 14^{\circ} 12^{\prime} 05.90^{\prime \prime} \mathrm{E}, 171 \mathrm{~m}\right]$. In the quarry, there were cut-machines with two saws, one working horizontally the other vertically in order to cur slabs of certain size for insulation and building blocks. Palletizing in situ, transportation, the annual extraction in late 1990s was reached 2,000,000 tn/yr, for building stones. The saw-dust [sand-gravel] derived during cuttings is used for soil amendment and feedstock, and the consumption is estimated 10,000 $\mathrm{tn} / \mathrm{yr}$. The tuff is homogenous, there is no bedding in the quarry, and there exist small volcanic fragments without zeolitization. The zeolite content is estimated to $40-70 \%$ and there is not any variation of the zeolite content attributed to stratigraphic situations of the beds. Their genesis is attributed to an open hydrological system. The sample NA6 was extracted from the Tufino quarry $\left[40^{\circ} 56^{\prime} 34.36^{\prime \prime} \mathrm{N}, 14^{\circ} 34^{\prime} 02.96^{\prime \prime} \mathrm{E}, 100 \mathrm{~m}\right]$. In this quarry, two different lithofacies are visible that characterise the Campanian Ignimbrite: an uppermost zeolite-bearing yellow formation [NYT] and a grey formation without zeolites [10,15-17]. The dimensions of the quarry are $500 \mathrm{~m} \times 300 \mathrm{~m} \times 30 \mathrm{~m}$. It is estimated that the zeolite content is $\sim 50 \%$. The specific raw material was marketed by IZ-Italiana Zeoliti of Pigneto (Modena, Italy) as CAB 70.

\subsubsection{Rome Area}

Several active and abandoned quarries of zeolitic tuffs exist in North of Rome. From the areas of Riano and Nepi two representative samples, labelled as ROM 2 and ROM3 were collected and analysed. The exploited material is dug out cut within a zeolitic tuff formation characterised as Red Tuff with Black Scoriae [15].

\section{a. Riano area (Rome Province, Latium)}

The zeolite quarry is named Falisca quarry that occurs at the south outskirts of the town Riano $\left[42^{\circ} 04^{\prime} 23.77^{\prime \prime} \mathrm{N}, 12^{\circ} 30^{\prime} 37.34^{\prime \prime} \mathrm{E}, 51 \mathrm{~m}\right]$. The stratigraphy of the volcanic sequence at Riano is quite complex. Three different volcanic formations can be recognised belonging to Vico Volcanic Complex. The stratigraphically lower tuffs are characterised by alternating levels of yellow tuffs, cinerite, leucitic scoriae and pumice [18-20]. The upper tuffs are trachytic to trachy-phonolitic massive ignimbrite named Red Tuff with Black Scoriae, constituted by pumiceous, gray matrix that contains black pumice fragments [15].

A third tuff deposit is chaotic agglomerate which contains volcanic particles of various sizes and also fragments of limestone and metamorphic rocks [15]. The entire succession of the yellow and red tuff is exposed in the quarry having some $50 \mathrm{~m}$ thickness. Size of the quarry: $500 \mathrm{~m} \times 100 \mathrm{~m} \times 40 \mathrm{~m}$. The sample ROM 2 was collected from the yellow tuff that underlies the red tuff. The gray is of better quality, harder, more compact and resistant. The red/brown tuff is not good for bricks, as it commonly has fractures. The zeolite tuff of Riano is denser, as it is older, than the NYT.

b. Nepi area (Viterbo Province)

The deposits occur some $2 \mathrm{~km}$ south of the town of Nepi (Viterbo Province, Latium). The analysed sample comes from a quarry named Romana Tufo quarry located north of Nepi, just outside the town $\left[42^{\circ} 13^{\prime} 13.94^{\prime \prime} \mathrm{N}, 12^{\circ} 20^{\prime} 58.41^{\prime \prime} \mathrm{E}, 185 \mathrm{~m}\right]$. The exploited material is dug out of the zeolitized levels of the same ignimbrite unit described above. The current production of this quarry is 200,000 $\mathrm{tn} / \mathrm{yr}$. The sample ROM 3 was extracted from the yellow tuff beds. 


\subsubsection{Viterbo-Pitigliano-Sorano Area}

In the area around Bolsena Lake there exist quite enough old and active zeolite tuff quarries, some of them being the most significant ones in the country. The tuff belongs to the formation of the Orvieto-Bagnoregio ignimbrite (OBI) (Vulsini volcanic district, Central Italy), locally called red tuff with black scoriae [6,21]. In Bagnoregio there exist the entire stratigraphic succession of Lower Pliocene marlstone, blue-yellow clays, followed upwards by sandstone, lapilli tuffs and finally by the red-brown tuffs (uppermost).

In Palombara quarry, located $2 \mathrm{~km}$ NE from Lubriano village, is present the most lightcoloured gray-yellowish tuff among all the Italian samples $\left[42^{\circ} 38^{\prime} 25.55^{\prime \prime} \mathrm{N}, 12^{\circ} 07^{\prime} 58.20^{\prime \prime} \mathrm{E}\right.$, $389 \mathrm{~m}]$. The exploited zeolite tuff is a phonolitic- leucititic-trachytic tuff with fragments of pumice. The samples SRN-1 and SRN2 were collected in two periods from a quarry extended in an area of about $60,000 \mathrm{~m}^{2}$ named Piandirena. It is located close to the town of Sorano (Grosseto Province, Tuscany) and currently is the most important active zeolite tuff quarry in Italy [ $\left.42^{\circ} 41^{\prime} 27.01^{\prime \prime} \mathrm{N}, 11^{\circ} 44^{\prime} 39.18^{\prime \prime} \mathrm{E}, 451 \mathrm{~m}\right]$. The samples represent bulk mined and gravelled zeolite tuff that is stockpiled for distribution to the market as soil amendment. The exploited material comes from a tough, highly zeolitized body known as Lithic Yellow Tuff (Sorano Formation) of the Làtera Volcanic Complex [22]. This unit consists of ash-fall tuff and pumice tuff with yellowish colour. The Lithic Yellow Tuff overlies the Red Tuff with Black Pumice unit, the contact between the two units being clearly visible on the quarry walls [15].

\subsection{Analytical Techniques}

Seven representative samples were extracted from the above areas. The samples were dried, crushed and separated in several portions. Part of each sample was ground to obtain fine fractions, for mineralogical and chemical analysis, whereas chip samples were used for SEM analysis.

\subsubsection{Mineralogical Analysis}

XRD mineralogical analysis of the tuff bulk samples was performed in NKUA, Dept of Geology and Geoenvironment. The samples were crushed, milled for $1 \mathrm{~min}$ and homogenised and run by X-ray diffraction, on a Siemens Model 5005 X-ray diffractometer in combination with the DIFFRACplus software package.

\subsubsection{Scanning Electron Microscopy}

Free surfaces of chip samples were gold coated and used for the scanning electron microscopy (SEM) study on a Philips XL-20 scanning electron microscope equipped with an EDAX energy dispersive X-ray fluorescence analyser in the laboratory of the Hellenic Centre for Marine Research (HCMR) at Anavyssos, south Attica.

\subsubsection{Bulk Rock Chemistry}

Chemical analyses of the studied samples (major and trace elements) were performed by XRF method (SRS 3400 wavelength dispersive XRF Spectrometer, Bruker and Epsilon 5 energy dispersive XRF Spectrometer Panalytical, accordingly) in TITAN SA laboratories at Kamari Viotia Plant.

\section{Results and Discussion}

The XRD mineralogical analysis results of the tuff samples are presented in Table 1. All samples studied contain chabazite and/or phillipsite and rarely analcime (Figure 1).

The results of chemical analysis of the zeolite tuff rock samples are presented in Table 2. According to their chemistry, all tuffs studied exhibit shoshonitic affinity and trachytic composition (Figure 2). All Italian tuffs studied have different mineralogy and chemistry compared to those originated from the Balkans and Hungary which are rich in clinoptilolite and/or mordenite and are also used in construction (building stones and cement raw material) $[5,23,24]$. 
Table 1. Results of the XRD mineralogical analysis of the zeolite tuff samples ${ }^{1}$.

\begin{tabular}{ccccccc}
\hline \multirow{2}{*}{ Sample } & \multicolumn{5}{c}{ Mineral Phases $^{2}$} \\
\cline { 2 - 6 } & Phil & Chab & Qtz & Sm/Sep & Fl & Ill \\
\hline SRN-1 & & MJ & & & TR & TR \\
SRN-2 & & MJ & & & TR & TR \\
VIT-1 & MJ & & & TR & TR \\
ROM-2 & MD & MJ & TR & TR & MD & TR \\
ROM-3 & TR & MJ & MD & MD & TR & TR \\
NAP-1 & MJ & TR & & & MD & TR \\
NAP-2 & MJ & MD & & & MJ & TR \\
\hline
\end{tabular}

${ }^{1}$ Glassy phase is present in medium to trace amounts in all samples due to the partial zeolitaziation of the initial volcanic glass. It has been estimated by the height of the hump of the XRD patterns at 20-26 degrees $(2 \theta) ;{ }^{2}$ Phil $=$ phillipsite, $\mathrm{Chab}=$ chabazite, $\mathrm{Qtz}=$ quartz, $\mathrm{Sm} / \mathrm{Sep}=$ smectite/sepiolite, $\mathrm{Fl}=$ feldspars, Ill $=$ illite $\mathrm{Chl}=$ Clinochlore, $\mathrm{C} C=$ calcite, $\mathrm{Dol}=$ dolomite, $\mathrm{MJ}=$ major, $\mathrm{MD}=$ medium, $\mathrm{TR}=$ minor or trace component

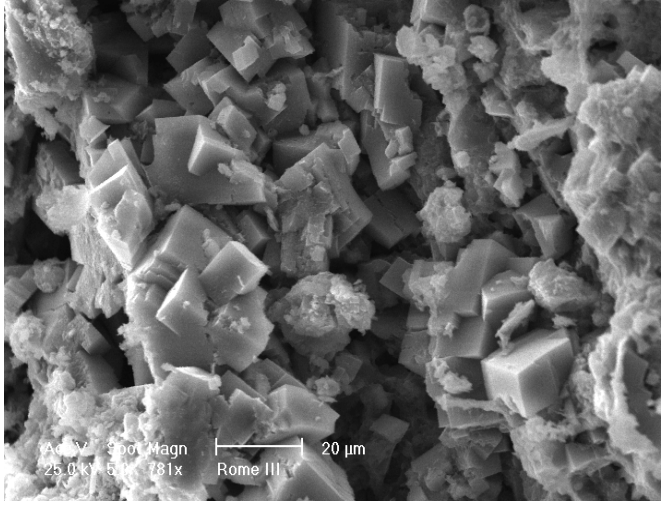

(a)

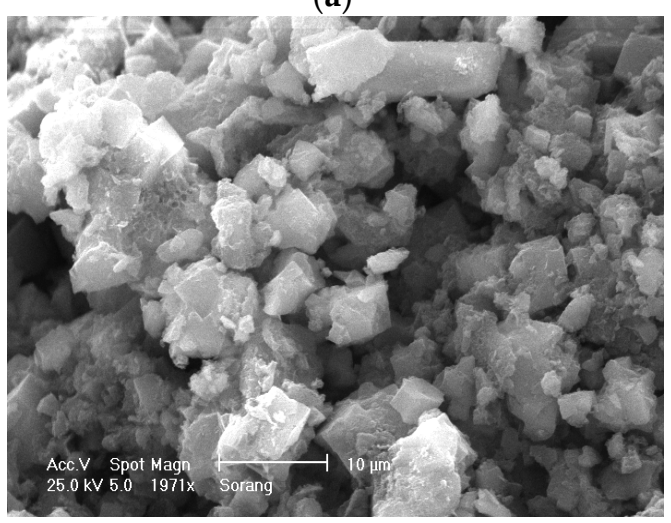

(c)

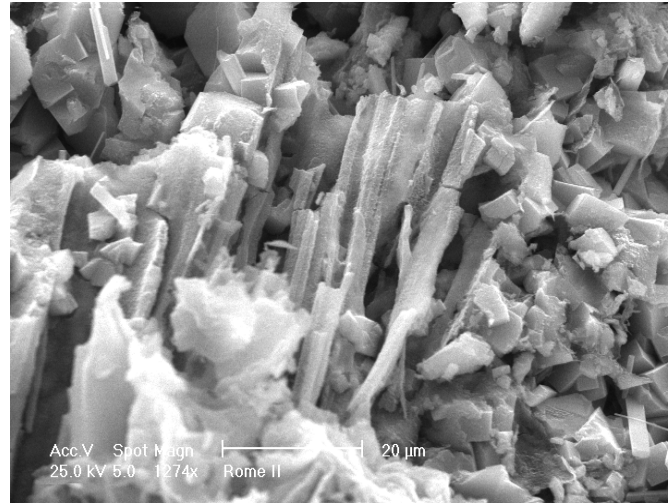

(b)

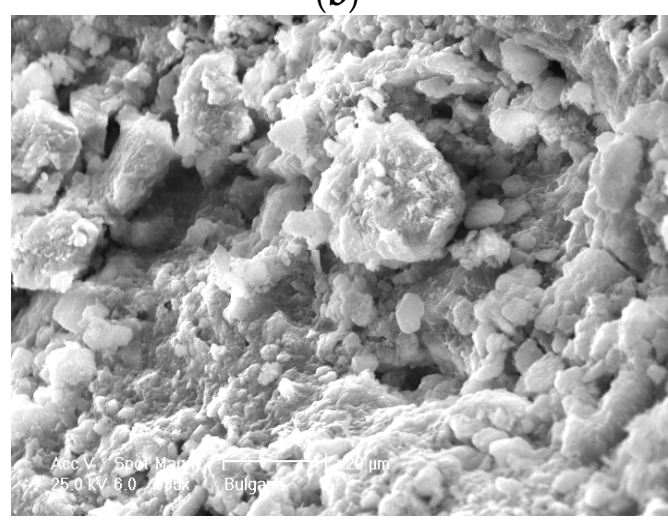

(d)

Figure 1. SEM micro-photographs of the Rome (a,b), Sorano (c) and Viterbo (d), zeolite tuff samples. Chabazite cubic crystals are observed in all photographs. The volcanic glass shards replacement by chabazite is noted in (a). 


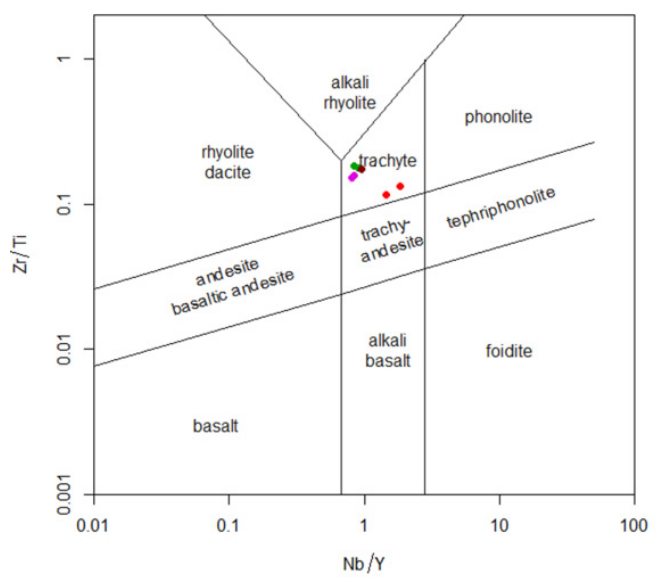

(a)

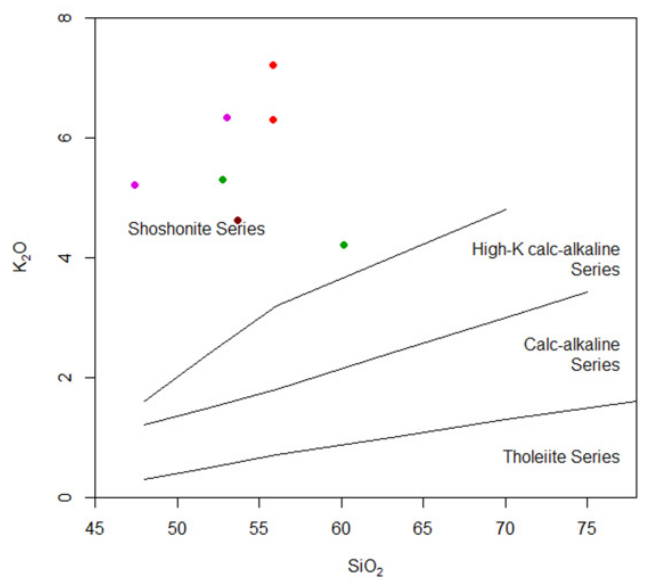

(b)

Figure 2. Plots of the Italian zeolite tuff samples (a) on the discrimination scheme of immobile elements $\mathrm{Nb}, \mathrm{Y}, \mathrm{Zr}$ and Ti modified by [25] and (b) on the classification scheme of [26].

Table 2. Chemical analysis of the zeolite tuff samples.

\begin{tabular}{|c|c|c|c|c|c|c|c|}
\hline & SOR-1 & SOR-2 & VIT-1 & NAP-1 & NAP-6 & ROM2 & ROM3 \\
\hline \multicolumn{8}{|l|}{$\%$} \\
\hline $\mathrm{SiO}_{2}$ & 60.17 & 52.77 & 53.68 & 55.82 & 55.85 & 53.02 & 47.40 \\
\hline $\mathrm{Al}_{2} \mathrm{O}_{3}$ & 12.22 & 17.05 & 16.47 & 16.95 & 16.63 & 17.03 & 14.72 \\
\hline $\mathrm{Fe}_{2} \mathrm{O}_{3}$ & 2.72 & 3.72 & 3.70 & 4.03 & 4.42 & 5.11 & 5.09 \\
\hline $\mathrm{CaO}$ & 5.12 & 5.40 & 4.84 & 2.02 & 4.20 & 4.69 & 9.83 \\
\hline $\mathrm{MgO}$ & 0.98 & 1.45 & 1.39 & 0.94 & 0.96 & 1.34 & 1.31 \\
\hline $\mathrm{K}_{2} \mathrm{O}$ & 4.21 & 5.30 & 4.62 & 7.22 & 6.31 & 6.34 & 5.22 \\
\hline $\mathrm{Na}_{2} \mathrm{O}$ & 0.84 & 0.63 & 0.67 & 2.08 & 0.95 & 1.22 & 0.54 \\
\hline $\mathrm{P}_{2} \mathrm{O}_{5}$ & 0.35 & 0.41 & 0.25 & 0.68 & 0.65 & 0.77 & 0.50 \\
\hline $\mathrm{SO}_{3}$ & 0.07 & 0.09 & 0.14 & 0.11 & 0.10 & 0.40 & 0.12 \\
\hline $\mathrm{TiO}_{2}$ & 0.41 & 0.48 & 0.43 & 0.40 & 0.43 & 0.52 & 0.46 \\
\hline $\mathrm{MnO}$ & 0.07 & 0.09 & 0.06 & 0.07 & 0.10 & 0.08 & 0.07 \\
\hline LOI & 13.03 & 12.75 & 13.91 & 9.67 & 9.35 & 9.74 & 15.05 \\
\hline Total & 100.19 & 100.14 & 100.16 & 99.99 & 99.95 & 100.30 & 100.31 \\
\hline \multicolumn{8}{|l|}{ ppm } \\
\hline $\mathrm{Cl}$ & 193 & 211 & 120 & 390 & 263 & 248 & 191 \\
\hline Sc & $\mathrm{BDL}^{1}$ & BDL & BDL & BDL & BDL & BDL & BDL \\
\hline V & 65 & 91 & 67 & 71 & 58 & 108 & 97 \\
\hline $\mathrm{Cr}$ & 2 & 3 & 13 & 2 & 2 & 3 & 39 \\
\hline $\mathrm{Co}$ & 5.2 & 6.6 & 6.6 & 7 & 9 & 12 & 17 \\
\hline $\mathrm{Ni}$ & 4 & 3.4 & 8 & 2 & 4 & 8 & 21 \\
\hline $\mathrm{Cu}$ & 16 & 28 & 32 & 73 & 47 & 44 & 113 \\
\hline $\mathrm{Zn}$ & 73 & 91 & 79 & 168 & 232 & 261 & 120 \\
\hline $\mathrm{Ga}$ & 21 & 26 & 19 & 18 & 19 & 22 & 17 \\
\hline $\mathrm{Ge}$ & 1 & 1 & 1 & 2 & 2 & 0.7 & 0.7 \\
\hline As & 12.7 & 13.2 & 9 & 12 & 3 & 37 & 14 \\
\hline Se & 3 & 2.3 & 2.5 & 2 & 3 & 4 & 3 \\
\hline $\mathrm{Br}$ & 3.4 & 1.7 & 2.7 & 1 & 1 & 1.6 & 1 \\
\hline $\mathrm{Rb}$ & 425 & 465 & 390 & 269 & 279 & 452 & 255 \\
\hline $\mathrm{Sr}$ & 874 & 926 & 1078 & 535 & 498 & 1042 & 1757 \\
\hline $\mathrm{Y}$ & 25 & 31 & 24 & 25 & 29 & 31 & 32 \\
\hline $\mathrm{Zr}$ & 446 & 509 & 449 & 275 & 343 & 492 & 415 \\
\hline $\mathrm{Nb}$ & 21 & 28 & 23 & 36 & 53 & 26 & 26 \\
\hline Mo & 0.5 & 0.1 & 1 & 1 & 0.7 & 2.3 & 0.7 \\
\hline
\end{tabular}


Table 2. Cont.

\begin{tabular}{cccccccc}
\hline & SOR-1 & SOR-2 & VIT-1 & NAP-1 & NAP-6 & ROM2 & ROM3 \\
\hline $\mathrm{ppm}$ & & & & & & & \\
\hline $\mathrm{Ag}$ & 0.1 & 0.1 & $\mathrm{BDL}$ & 1 & 0.2 & 0.1 & 0.5 \\
$\mathrm{Cd}$ & 0.9 & 1.2 & 0.5 & 2.4 & 5.5 & 7 & 35 \\
$\mathrm{Sn}$ & 4.9 & 4.6 & 3.5 & 4.6 & 5 & 6 & 5 \\
$\mathrm{Sb}$ & 1 & 1.1 & 0.4 & 1 & 0.5 & 4 & 4 \\
$\mathrm{Te}$ & 0.7 & 1.1 & 0.1 & $\mathrm{BDL}$ & 0.2 & 0.1 & $\mathrm{BDL}$ \\
$\mathrm{I}$ & $\mathrm{BDL}$ & $\mathrm{BDL}$ & 0.4 & $\mathrm{BDL}$ & 0.1 & 0.9 & 1.2 \\
$\mathrm{Cs}$ & 44 & 48.8 & 41 & 15 & 18 & 56 & 35 \\
$\mathrm{Ba}$ & 454 & 503 & 436 & 868 & 459 & 743 & 618 \\
$\mathrm{La}$ & 118 & 138 & 102 & 60 & 76 & 142 & 144 \\
$\mathrm{Sm}$ & 9 & 7 & 8 & 7 & 8 & 11 & 10 \\
$\mathrm{Ce}$ & 203 & 234 & 188 & 108 & 129 & 250 & 243 \\
$\mathrm{BDL}$ & 73 & 86 & 65 & 45 & 52 & 95 & 90 \\
$\mathrm{Yb}$ & 0.4 & 0.9 & $\mathrm{BDL}$ & 4 & $\mathrm{BDL}$ & 0.6 & $\mathrm{BDL}$ \\
$\mathrm{Hf}$ & 5.4 & 6 & 4.3 & $\mathrm{BDL}$ & 2 & 3.7 & $\mathrm{BDL}$ \\
$\mathrm{W}$ & 13 & 6 & 9 & 9 & 17 & 8 & 18 \\
$\mathrm{Hg}$ & 0.7 & 0.8 & 0.8 & 0.5 & 0.4 & 0.6 & 0.5 \\
$\mathrm{Tl}$ & 3 & 3.7 & 1.7 & 1.9 & 2.4 & 1.6 & 1 \\
$\mathrm{~Pb}$ & 103 & 106 & 96 & 54 & 52 & 108 & 193 \\
$\mathrm{Bi}$ & 0.8 & 1.3 & 1.9 & 0.9 & 0.8 & 1.9 & 2.9 \\
$\mathrm{Th}$ & 60 & 83 & 72 & 20 & 16 & 99 & 76 \\
\hline
\end{tabular}

${ }^{1} \mathrm{BDL}=$ below detection limit.

These differences suggest an origin from a different parent magma, which plays an important role in the kind of the zeolites formed. The occurrence of glassy tuffs above the Italian zeolitized tuffs studied is in order with the model proposed by other authors (e.g., [16]) concluding an early zeolite diagenesis of the volcanic glass in open hydrological systems. Nevertheless, the diversity of the chemistry and zeolite mineralogy do not play the major role for the utilisation of those tuffs in the construction industry. Other parameters, such as porosity, abrasion resistance, compressive and flexural strength, may be crucial for the commercial exploitation of zeolite tuffs as building materials.

\section{Conclusions}

All tuff samples studied contain chabazite and/or phillipsite and rarely analcime. The zeolite content of the NYT is up to $75 \%$, comparable to those from Rome area. In Bolsena District the tuffs have zeolite content up to $90 \%$. In the zeolitized tuffs from Naples, phillipsite predominates, whereas Bolsena and Rome zeolitized tuffs are rich in both chabazite and phillipsite.

SEM analysis revealed that there is an extensive replacement of the volcanic glass by subhedral zeolite, whereas in pore spaces and fissures, euhredral zeolite crystals occur. In some samples the ground masses contain mainly chabazite, whereas the fragments are phillipsite-rich.

Two different types of chabazite, have been identified according to their XRD patterns; a Ca-rich and a $\mathrm{Ca}, \mathrm{Mg}, \mathrm{K}, \mathrm{Na}$-rich, both accompanying $\mathrm{K}$ - and Na-rich phillipsite. This could be attributed to the chemistry of the original volcanic glass, but also to the presence of alkali and alkaline earths-rich pore fluids.

According to their bulk chemistry, all tuffs studied exhibit shoshonitic affinity and trachytic composition. Their comparison with zeolite tuffs from Balkans suggested that the chemistry of the original volcanic glass phases and the parent magma plays an important role in the kind of the zeolites formed.

The occurrence of glassy tuffs above the Italian zeolitized tuffs studied is a characteristic model for an early zeolite diagenesis of the volcanic glass in open hydrological systems. 
However, the diversity of the chemistry and zeolite mineralogy is not a critical factor for the utilisation of those tuffs in the construction industry.

Author Contributions: Conceptualisation, M.G.S. and C.V.; methodology, M.G.S. and C.V.; sampling, I.S.S., validation, M.G.S., C.V. and I.S.S.; writing—original draft preparation, M.G.S. and I.S.S.; writing-review and editing, C.V.; visualisation, C.V. All authors have read and agreed to the published version of the manuscript.

Funding: This research received no external funding.

Institutional Review Board Statement: Not applicable.

Informed Consent Statement: Not applicable.

Acknowledgments: National and Kapodistrian University of Athens-Special Account for Research Grands is kindly thanked for funding the presentation of this work. Thanks are expressed to Hellenic Centre for Marine Research personnel for helping with SEM analysis. The staff of the R\&D TITAN Cement plant at Kamari Votia are also thanked.

Conflicts of Interest: The authors declare no conflict of interest.

\section{References}

1. Marantos, I.; Christidis, G.E.; Ulmanu, M. Zeolite formation and deposits. In Handbook of Natural Zeolites; Inglezakis, V.J., Zorpas, A.A., Eds.; Bentham Science Publishers: Sharjah, United Arab Emirates, 2011; pp. 28-51.

2. Gottardi, G.; Obradovic, J. Sedimentary Zeolites in Europe. Fortschr. Miner. 1978, 56, 316-366.

3. Hay, R.L.; Sheppard, R.A. Zeolites in Open Hydrologic Systems. In Mineralogy and Geology of Natural Zeolites; Mumpton, F.A., Ed.; Mineralogical Society of America Reviews in Mineralogy: Chantilly, VA, USA, 1981; Volume 4, pp. 93-102.

4. Sheppard, R.A. Descriptive Model of Sedimentary Zeolites-Deposit Subtype: Zeolites in Tuffs of Open Hydrologic Systems. In Some Industrial Mineral Deposit Models: Descriptive Deposit Models; Open-File Report, 91-11A; Orris, G.J., Bliss, J.D., Eds.; U.S. Geological Survey: Reston, VA, USA, 1991; pp. 13-15.

5. Stamatakis, M.G.; Hall, A.; Hein, J.R. The zeolite deposits of Greece. Miner. Depos. 1996, 31, 473-481. [CrossRef]

6. de Gennaro, M.; Langella, A. Italian zeolitized rocks of technological interest. Miner. Depos. 1996, 31, 452-472. [CrossRef]

7. Stamatakis, M.G.; Hall, A.; Lutat, U.; Walsh, J.N. Mineralogy, origin and commercial value of the zeolite-rich tuffs in the Petrota $\neg$-Pentalofos area, Evros County, Greece. Estud. Geol. 1998, 54, 315-322. [CrossRef]

8. Virta, R.L. Zeolites (Natural). In Mineral Commodity Summaries; U.S. Geological Survey: Reston, VA, USA, 2015; pp. 184-185.

9. de Gennaro, M.; Colella, C.; Franco, E.; Aiello, R. Italian zeolites 1. Mineralogical and technical features of Neapolitan yellow tuff. Ind. Miner. 1983, 186, 47-53.

10. Perrotta, A.; Scarpati, C. Plinian versus co-ignimbrite volume in large explosive eruptions: The example of the Campanian Ignimbrite eruption. Miner. Petrol. 2003, 79, 67-78. [CrossRef]

11. De Gennaro, R.; Cappelletti, P.; Cerric, G.; de'Gennaro, M.; Dondi, M.; Langella, A. Neapolitan Yellow Tuff as raw material for lightweight aggregates in lightweight structural concrete production. Appl. Clay Sci. 2005, 28, 309-319. [CrossRef]

12. Caputo, D.; Lucolano, F.; Pepe, F.; Colella, C. Modeling of water and ethanol adsorption data on a commercial zeolite-rich tuff and prediction of the relevant binary isotherms. Microporous Mesoporous Mater. 2007, 105, 260-267. [CrossRef]

13. Pansini, M.; de Gennaro, R.; Parlato, L.; de'Gennaro, M.; Langella, A.; Marocco, A.; Cappelletti, P.; Mercurio, M. Use of Sawing Waste from Zeolitic Tuffs in the Manufacture of Ceramics. Adv. Mater. Sci. Eng. 2010, 2010, 820541. [CrossRef]

14. Jackson, M.D.; Chae, S.R.; Mulcahy, S.R.; Meral, C.; Taylor, R.; Li, P.; Emwas, A.H.; Moon, J.; Yoon, S.; Vola, G.; et al. Unlocking the secrets of Al-tobermorite in Roman seawater concrete. Am. Mineral. 2013, 98, 1669-1687. [CrossRef]

15. Passaglia, E.; Vezzalini, G. Crystal chemistry of diagenetic zeolites in volcanoclastic deposits of Italy. Contrib. Mineral. Petrol. 1985, 90, 190-198. [CrossRef]

16. de'Gennaro, M.; Cappelletti, P.; Langella, A.; Perrotta, A.; Scarpati, C. Genesis of zeolites in the Neapolitan Yellow Tuff: Geological, volcanological and mineralogical evidence. Contrib. Mineral. Petrol. 2000, 139, 17-35. [CrossRef]

17. de'Gennaro, B.; Aprea, P.; Colella, C. Impianto pre-pilota per la rimozione di ammonio da reflui dell'industria conciaria con letti di tufo zeolitico. In Proceedings of the $6^{\circ}$ Convegno Nazionale AIMAT, Modena, Italy, 8-11 September 2002.

18. Sparks, R.S.J. Stratigraphy and geology of the ignimbrites of Vulsini Volcano Central Italy. Geol. Rundsch. 1975, 64, 497-523. [CrossRef]

19. Lombardi, G. Thermal analysis in the investigation of zeolitized and altered volcanics of Latium, Italy. Clay Miner. 1984, 19, 789-801. [CrossRef]

20. Laurora, A.; Vezzalini, M.G.; Brigatti, M.F.; Malferrari, D. Technical report on: Mineralogical features of the quarry materials. In Water Pollution Reduction and Water Saving Using Natural Zeolitite Cycle Life. LIFE+2010—Project Code: LIFE+10ENV/IT/000321; Deliverable Product of the UniMORE Research Units: Modena, Italy, 2012; 20p. 
21. de Gennaro, B.; Colella, A.P.; Aprea, P.; Colella, C. Evaluation of an intermediate-silica sedimentary chabazite as exchanger for potentially radioactive cations. Microporous Mesoporous Mater. 2003, 61, 159-165. [CrossRef]

22. Vezzoli, L.; Conticelli, S.; Innocenti, F.; Landi, P.; Manetti, P.; Palladino, D.M.; Trigila, R. Stratigraphy of the Latera Volcanic Complex: proposals for a new nomenclature. Per. Mineral. 1987, 56, 89-110.

23. Stamatakis, M.G.; Fragoulis, D.; Papageorgiou, A.; Chaniotakis, E.; Bedelean, J.; Csiric, G. Clinoptilolite-rich tuffs from Greece, Romania and Hungary and their industrial potential as cement additive. In Proceedings of the 3rd Congress of Mineral Wealth, Athens, Greece, 22-24 November 2000; pp. 451-457.

24. Stamatakis, M.G.; Stamataki, I.S.; Giannatou, S.; Vasilatos, C.; Drakou, F.; Mitsis, I.; Xinou, K. Characterization and evaluation of chabazite-and mordenite-rich tuffs, and their mixtures as soil amendments and slow release fertilizers. Arch. Agron. Soil Sci. 2017, 63, 735-747. [CrossRef]

25. Pearce, J.A. A User's Guide to Basalt Discrimination Diagrams. In Trace Element Geochemistry of Volcanic Rocks: Applications for Massive Sulphide Exploration; Wyman, D.A., Ed.; Geological Association of Canada, Short Course Notes: Ottawa, ON, Canada, 1996; Volume 12, pp. 79-113.

26. Peccerillo, A.; Taylor, S.R. Geochemistry of Eocene Calc-Alkaline Volcanic Rocks from the Kastamonu Area, Northern Turkey. Contrib. Mineral. Petrol. 1976, 58, 63-81. [CrossRef] 